\title{
Saharan Dust Events over the Valencian Community (Eastern Iberian Peninsula): Synoptic Circulation Patterns and Contribution to $\mathbf{P M}_{10}$ Levels
}

\author{
Ariadna Huerta-Viso, Javier Crespo, Nuria Galindo, Eduardo Yubero, Jose Francisco Nicolás \\ Atmospheric Pollution Laboratory (LCA), Department of Applied Physics, Miguel Hernández University, Avenida de la \\ Universidad S/N, 03202 Elche, Spain
}

\begin{abstract}
This study assessed Saharan dust events (SDE) passing over the Valencian Community (VC; eastern Spain) during the period of 2014-2017 by investigating the following topics: a) the occurrence of SDE and their impact on $\mathrm{PM}_{10}$ mass concentrations, b) the identification of the favorable synoptic patterns at $850 \mathrm{hPa}$ associated with SDE via cluster analysis and c) the applicability of the gamma probability density function (PDF) in fitting the mass contributions of SDE. We determined that these events affect the $\mathrm{VC}$ on $\sim 26 \%$ of the days of the year, thereby contributing $3.3 \mu \mathrm{g} \mathrm{\textrm {m } ^ { - 3 }}(\sim 23 \%)$ to the average $\mathrm{PM}_{10}$ concentration. Five circulation scenarios were identified. In Scenario 1 (17.4\%), the transport of Saharan dust was due to the combination of a trough situated over the southwest of the Iberian Peninsula and a high-pressure system centered on western Algeria, Tunisia and eastern Libya. According to the PDF analysis, SDE characterized by this type of pattern were the most likely to substantially increase $\mathrm{PM}_{10}$ mass concentrations. In Scenarios $3(39.2 \%)$ and 5 (19.4\%), which contributed to high concentrations of mineral dust in the VC, a high-pressure system was located over North Africa. Scenarios 1, 3 and 5 occurred more frequently during summer, especially Scenario 3 (69\%). On the other hand, Scenarios 2 $(16.2 \%)$ and $4(7.2 \%)$, both characterized by a deep low over the west or northwest of the Iberian Peninsula, typically arose during spring and, to a lesser extent, winter. These two scenarios displayed a lower probability of elevating mineral dust levels in the study area.
\end{abstract}

Keywords: $\mathrm{PM}_{10}$; Meteorological scenario; Cluster analysis; Saharan dust; Gamma distribution.

\section{INTRODUCTION}

The impact of mineral dust advections from arid regions of North Africa on the air quality in European Mediterranean countries may be very significant. This is due to the long residence time of particulate matter (PM) in the atmosphere induced by the low precipitation in the Mediterranean Basin (Querol et al., 2009). As a result of this long-range transport, PM concentrations increase and its chemical composition changes (Galindo et al., 2020). This leads to variations in the morbidity-mortality pattern associated with airborne PM levels. In fact, Saharan dust events (SDE) may be a risk factor for daily mortality (Díaz et al., 2017). Two main reasons may explain the harmful effects of desert dust on human health: the high concentrations of mineral dust recorded during these episodes, and the anthropogenic, biological and microbiological load of dust outbreaks (Querol et al., 2019b). These effects are mainly related to cardiovascular and

\footnotetext{
* Corresponding author.

Tel.: +34966658325

E-mail address: j.nicolas@umh.es
}

respiratory disorders, but it can also produce skin irritations, conjunctivitis, etc. (Goudie et al., 2014).

Several studies carried out in the Mediterranean Basin have analyzed the impact of SDE on human health. Most of these works are related to the effects of coarse particles, since the associations between exposure to the fine fraction $\left(\mathrm{PM}_{2.5}\right)$ and human health effects during SDE are not usually statistically significant (Karanasiou et al., 2012). Jiménez et al. (2010) identified the $\mathrm{PM}_{10}$ fraction as the best air quality indicator for evaluating short-term human health effects of PM during SDE. Mallone et al. (2011) observed that $\mathrm{PM}_{10}$ concentrations during dust days caused an important increase in cardiac mortality compared to dust-free days. A review of European studies on the health effects of Saharan dust can be consulted in Karanasiou et al. (2012).

Mineral dust also has a relevant role in the climate system. Mineral particles have a slight net cooling effect, although with a high level of uncertainty. Its direct radiative forcing varies between -0.3 and $+0.1 \mathrm{~W} \mathrm{~m}^{-2}$ at a global scale (IPCC, 2013). Nevertheless, the effects can be much greater at a local scale, especially close to source regions (García et al., 2011).

Certain meteorological patterns at a synoptic scale are responsible for dust transport from the Saharan region towards higher latitudes. Thus, mineral dust can reach European 
countries located in the Mediterranean Basin or, although less frequently, more northern regions. These scenarios have been described in some previous studies performed in the Mediterranean area (Escudero et al., 2005; Meloni et al., 2008; Nastos, 2012; Valenzuela et al., 2012; Salvador et al., 2014). The characterization of these advections is relevant for further prediction, as well as for the implementation of preventive measures to minimize the health impacts. The frequency of days with Saharan influence in a certain location depends on the specific meteorological scenarios and the distance to dust sources (Díaz et al., 2017). This frequency (on an annual basis) oscillates between $17 \%$ and $37 \%$ along the Mediterranean Basin (Pey et al., 2013), and its percentage contribution to $\mathrm{PM}_{10}$ levels decreases with latitude. Specifically, for the Iberian Peninsula, the contribution of Saharan dust to $\mathrm{PM}_{10}$ concentrations varies between percentages higher than $20 \%$ in the southeast to values lower than $10 \%$ in the north (Querol et al., 2019a). African desert dust episodes also show some seasonality, so its contribution to PM levels can vary throughout the year. In the western Mediterranean, African dust inputs are considerably higher between May and October (Pey et al., 2013).

The present study aims to characterize the impact of SDE on $\mathrm{PM}_{10}$ background levels in eastern Spain. Besides quantifying the contribution of these events to $\mathrm{PM}_{10}$ mass concentrations, the scenarios that trigger the transport of mineral dust to the studied region will be discussed. Finally, the distribution of the Saharan inputs obtained for each meteorological scenario will be simulated by using a probability function. By doing so, threshold concentrations can be predicted as a function of the meteorological pattern.

\section{MATERIAL AND METHODS}

\section{Monitoring Site}

$\mathrm{PM}_{10}$ data used in this study were obtained from the air quality monitoring station Caudete de las Fuentes $\left(1^{\circ} 16^{\prime} 43^{\prime \prime} \mathrm{W}\right.$, $39^{\circ} 33^{\prime} 30^{\prime \prime} \mathrm{N}, 794 \mathrm{~m}$ a.s.1.), belonging to the Environmental Surveillance Network of the regional Government of Valencia. The site is located inland, $\sim 83 \mathrm{~km}$ from the Mediterranean coast, in the Valencian Community (VC), in eastern Spain (Fig. 1). This location is highly sensitive to SDE due to its proximity to the African continent, its height above sea level and its distance from anthropogenic sources (the station can be classified as regional background).

The study area is characterized by a typical Mediterranean climate, classified as $C s a$ in the Köppen climate classification, with mild winters and moderately hot and dry summers. Global mean temperatures range from $13.9^{\circ} \mathrm{C}$ in winter to $25.5^{\circ} \mathrm{C}$ in summer, with low annual precipitations around $450 \mathrm{~mm}$, concentrated primarily in spring and autumn.

$\mathrm{PM}_{10}$ data from the period 2014-2017 were analyzed in order to study its seasonal variation and the contribution of $\mathrm{SDE}$ to $\mathrm{PM}_{10}$ mass concentrations. For this, the year was divided into four seasons: winter (January-March), spring (April-June), summer (July-September) and autumn (October-December).

\section{SDE: Identification and Quantification of its Contribution to PM10 Levels}

The identification of SDE was based on the results of predictive models (SKIRON dust simulations [http://forecast.uoa.gr/dustindx.php], NRL NAAPS model [http://www.nrlmry.navy.mil/aerosol] and BSC-DREAM8b [http://www.bsc.es/ess/bsc-dust-daily-forecast]). The use of back-trajectory analysis by means of the HYSPLIT model (Draxler and Rolph, 2013) along with the analysis of $\mathrm{PM}_{10}$ time series helped to confirm the presence of SDE over the study area.

The procedure used to obtain the contribution of these events to $\mathrm{PM}_{10}$ mass concentrations in this work is the socalled " $40^{\text {th }}$ percentile method" (http://ec.europe.eu/environ ment/air/quality/legislationpdf/sec_2011_0208.pdf). This is the reference method for the determination of the contribution

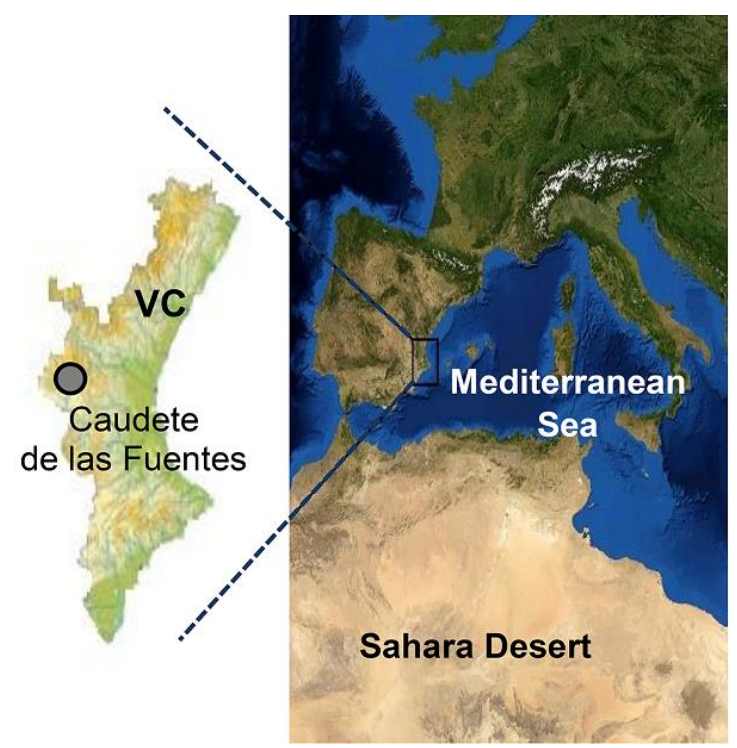

Fig. 1. Geographical location of the Valencian Community (VC) in the south eastern coast of the Iberian Peninsula and location of the monitoring site. 
of SDE (\% dust) to PM levels in Spain and Portugal since 2014, and it is applicable to southern European regions (Querol et al., 2009). The methodology is based on statistical data treatment of time series of PM concentrations recorded at regional background stations (RBS). The basis of this method can be found in Escudero et al. (2007) and Pey et al. (2008) and will be applied in this work under the name of $P 40$. The feasibility of this procedure has been demonstrated in several previous studies (Querol et al., 2009; Aleksandropoulou and Lazaridis, 2013; Ealo et al., 2016; Fernández et al., 2017; Nicolás et al., 2018; Conte et al., 2020). Recently, certain aspects of this methodology have been revised, mainly those associated with the estimation of the Saharan dust contribution to PM concentrations at urban sites (Barnaba et al., 2017). On the other hand, the application of this methodology may lead to an overestimation of the crustal contribution to PM levels when the contribution from other background sources is high, as can be the case of Lampedusa, an island located in the central Mediterranean Sea very close to the Tunisian coast (Marconi et al., 2014).

\section{Cluster Analysis of Meteorological Patterns}

Cluster analysis (CA) is a multivariate statistical technique that aims to classify elements (or variables) into different groups or clusters. This analysis seeks to maximize the homogeneity of elements within the clusters and also to maximize the heterogeneity among the clusters. The solution of the CA is not necessarily unique as it depends on the procedure used to group the elements. The reason is that different algorithms for grouping objects are available. In this study, the non-hierarchical k-means algorithm was chosen to classify atmospheric circulation patterns. It divides the data into $k$ clusters at random and calculates the centroid of each cluster, assigning each element to the closest cluster. Then, new centroids are computed and elements are reassigned to the closest new cluster. This process is repeated until no more reassignment can be made. The number of clusters is to be specified by the user prior to clustering.

This method has been used in similar previous studies with good results (Alonso-Pérez et al., 2011; Salvador et al., 2013, 2014). CA was applied on geopotential height daily fields at the $850 \mathrm{hPa}$ level for days under Saharan influence (362 days) during the 2014-2017 period. These data were obtained from the website https://www.esrl.noaa.gov/psd/d ata/composites/hour/ (Kalnay et al., 1996) of the National Centers for Environmental Prediction (NCEP). The domain of study extended from $15^{\circ} \mathrm{N}$ to $55^{\circ} \mathrm{N}$ latitude and from $25^{\circ} \mathrm{E}$ to $15^{\circ} \mathrm{W}$ longitude. The grid included a total of 289 points since each geopotential height covered an area of $2.5^{\circ}$ $\times 2.5^{\circ}$ (spatial resolution). As a result, an initial matrix with 362 rows $\times 289$ columns was formed.

The software used for the analysis was SPSS v.24. Each "dust day" was assigned to a cluster. Then, we calculated composite maps by averaging geopotential heights at $850 \mathrm{hPa}$ from the data of all days assigned to a particular cluster. The maps for each cluster were obtained using the Surfer software package (v.8.01). In this study, a total of 362 geopotential pressure maps have been grouped into 5 meteorological patterns that will be described in the "Results" section.

\section{Gamma Distribution}

The gamma probability distribution was selected to examine the frequency of the Saharan dust contribution to $\mathrm{PM}_{10}$ mass concentrations. This analysis was conducted for each cluster. The Kolmogorov-Smirnov test was used to evaluate the goodness of fit of the probability density function (PDF) to the data.

The gamma distribution is described as follows:

$$
f(x)=\frac{1}{\beta^{\alpha} \cdot \Gamma(\alpha)} x^{\alpha-1} \cdot e^{-x / \beta} ; x>0
$$

where $\Gamma(\alpha)$ is the gamma function, calculated as:

$$
\Gamma(\alpha)=\int_{0}^{\infty} x^{\alpha-1} \cdot e^{-x} d x
$$

The coefficients $\alpha$ and $\beta$ in the previous equation are the shape and scale parameters, respectively. Values of the $\alpha$ parameter are always greater than zero. Shape and scale parameters determine the maximum intensity and the right skewness of the distribution, respectively. To obtain both parameters, the method of moments was used.

In general, the gamma distribution can be useful to analyze pollution data. Besides, the distribution can provide the probability of exceedances of a certain limit value. With these objectives, several studies have successfully used this distribution (Hrdličková et al., 2008; Ozel and Cakmakyapan, 2015).

\section{RESULTS}

\section{PM10: Concentrations and Seasonality}

Fig. 2 shows seasonal $\mathrm{PM}_{10}$ concentrations at the monitoring site during the study period. As can be observed, the highest

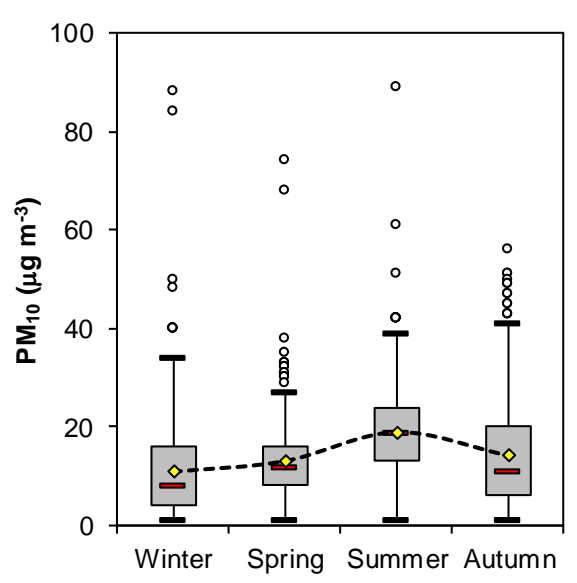

Fig. 2. Average seasonal concentration of $\mathrm{PM}_{10}$ for the 2014-2017 period. Yellow diamonds represent mean values and red rectangles represent median values. The whiskers correspond to the P25 and P75 quartiles. Maximum and minimum concentrations are represented by dashes (-). Circles denote outliers. 
mean $\mathrm{PM}_{10}$ value was reached in summer $\left(19.1 \mu \mathrm{g} \mathrm{m}^{-3}\right)$ and the lowest $\left(11.0 \mu \mathrm{g} \mathrm{m}^{-3}\right)$ in winter. The average $\mathrm{PM}_{10}$ concentration for the whole study period was $14.2 \mu \mathrm{g} \mathrm{m}^{-3}$. The seasonal variation and the average value of $\mathrm{PM}_{10}$ are typical of RBS in Spain (Querol et al., 2008, 2009), and in general in the western Mediterranean (Pey et al., 2013). On the other hand, all the outliers shown in Fig. 2 occurred on dust days. The average $\mathrm{PM}_{10}$ concentration recorded on days not affected by SDE throughout the study period was $11.5 \mu \mathrm{g} \mathrm{m}^{-3}$. This value increased to $22.2 \mu \mathrm{g} \mathrm{m}^{-3}$ when only dust days were considered. SDE are responsible for most of the exceedances of the European daily limit value for $\mathrm{PM}_{10}\left(50 \mu \mathrm{g} \mathrm{m}^{-3}\right)$ at RBS in Spain (Escudero et al., 2007; Querol et al., 2008, 2009). In this study, the limit value was exceeded on 12 days.

The higher summer $\mathrm{PM}_{10}$ levels are associated with: (a) higher resuspension rates, (b) increased production of secondary aerosols by photochemical reactions, (c) higher frequency of SDE, and (d) lower rainfall rates.

\section{Characterization of SDE}

Table 1 depicts a summary of the number of days under the influence of SDE $\left(\mathrm{N}_{\mathrm{SDE}}\right)$ according to the season for the four years of the study. Seasonal and annual percentage contributions are presented in brackets.

On average, there were 94 dust days per year. This implies that $\sim 26 \%$ of the days of the year were under the influence of SDE. This percentage is consistent with those obtained by Galindo et al. (2017) and Castañer et al. (2017) at a high mountain station (> $1500 \mathrm{~m}$ a.s.l.) located approximately $200 \mathrm{~km}$ southeast. This result indicates that the altitude of the sampling point is enough to be considered sensitive to most of the SDE passing over the VC. For the study area, it has been reported that mountain stations are more affected by SDE than sites located at lower altitudes, due to the altitude of the Saharan dust transport (Nicolás et al., 2014). Nevertheless, this result should be taken with caution. In the analysis of the spatiotemporal evolution of a severe winter dust event in Spain, Titos et al. (2017) showed that the maximum daily $\mathrm{PM}_{10}$ concentration does not always increase with altitude.

The high percentage of dust days at the monitoring site is also an indicator of the importance of Saharan mineral dust in the VC. As shown in Table 1, the number of dust days can vary considerably over the years. For instance, during $2017 \mathrm{~N}_{\mathrm{SDE}}$ was $32.5 \%$ higher than in 2014. On average, summer was the season with the highest percentage of dust days, while in winter the percentage fell to below $15 \%$. This result is in agreement with monthly frequencies obtained at other sites located in southern Spain (Valenzuela et al., 2012).
During the study period a total of 93 SDE were identified, with a mean value of $\sim 23$ episodes per year. Fig. 3 shows the number of Saharan events recorded throughout the study period according to their duration. The length of the episodes was divided into seven intervals. The figure also shows the relative frequency for each interval according to season.

As can be seen in Fig. 3, the frequency of episodes decreased as its lenght increased. The reduction in the number of events as a function of the length in days fitted well to a quadratic function $\left(\mathrm{R}^{2}=0.92\right)$. Long-lasting episodes (length $>13$ days) occurred more frequently during summer. During winter shorter episodes were recorded, while in autumn and spring the duration of these events ranged from 1 to 15 days. Therefore, there was a seasonal effect on the length of Saharan dust events. The average duration of these episodes was lowest during winter $\left(2.1\right.$ days episode $\left.{ }^{-1}\right)$, followed by autumn (3.6 days episode ${ }^{-1}$ ), spring (4.1 days episode ${ }^{-1}$ ) and summer (6.7 days episode $\left.{ }^{-1}\right)$. The longest episode lasted 20 days and was recorded in July 2015. The average duration of SDE throughout the study period was about 4 days. The mean episode duration and the average number of episodes per year were slightly greater than those obtained in Central Spain during the 2001-2008 period (Salvador et al., 2013) or south-eastern Italy over a six year period (2013-2018) (Conte et al., 2020). They were also higher than those previously reported for the same study area over the period 1996-2002 (Escudero et al., 2005).

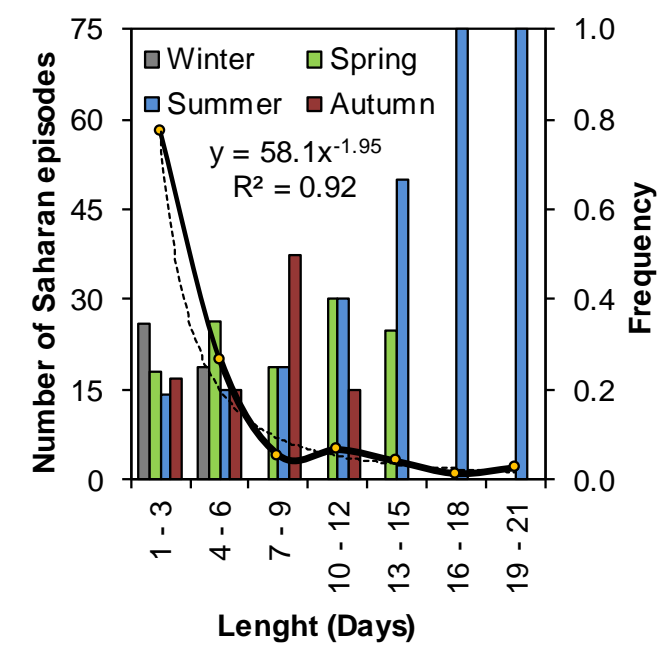

Fig. 3. Number of Saharan events identified throughout the study period according to their length (black line). The figure also shows the relative frequency of Saharan episodes for each season.

Table 1. Number of dust days $\left(\mathrm{N}_{\mathrm{SDE}}\right)$ by season and year throughout the study period. Seasonal and annual percentage contributions are presented in brackets.

\begin{tabular}{llllll}
\hline & 2014 & 2015 & 2016 & 2017 & Mean \\
\hline Winter & $12(15.2 \%)$ & $8(8.7 \%)$ & $9(10.2 \%)$ & $23(19.7 \%)$ & $\sim 13(14.3 \%)$ \\
Spring & $27(34.2 \%)$ & $22(23.9 \%)$ & $13(14.8 \%)$ & $41(35.0 \%)$ & $\sim 26(28.6 \%)$ \\
Summer & $14(17.7 \%)$ & $43(46.7 \%)$ & $50(56.8 \%)$ & $47(40.2 \%)$ & $\sim 39(42.8 \%)$ \\
Autumn & $26(32.9 \%)$ & $19(20.6 \%)$ & $16(18.2 \%)$ & $6(5.1 \%)$ & $\sim 17(18.6 \%)$ \\
Annual & $79(21.6 \%)$ & $92(25.2 \%)$ & $88(24.1 \%)$ & $117(32.1 \%)$ & $94(25.8 \%)$ \\
\hline
\end{tabular}




\section{SDE: Mass Contribution to PM10 Concentrations}

Table 2 shows the seasonal contribution of Saharan outbreaks to $\mathrm{PM}_{10}$ levels calculated using the $\mathrm{P} 40$ method. The percentage contribution of Saharan dust to the seasonal average $\mathrm{PM}_{10}$ values is shown in brackets.

The annual contribution of SDE to $\mathrm{PM}_{10}$ concentrations ranged from $2.8 \mu \mathrm{g} \mathrm{m}^{-3}$ in 2017 to $4.0 \mu \mathrm{g} \mathrm{m}^{-3}$ in 2016. The average percentage contribution of Saharan dust to annual $\mathrm{PM}_{10}$ values ranged from $19.4 \%$ to $27.4 \%$. Seasonal contributions varied between $6.2 \%$ (summer 2014) and $40.2 \%$ (winter 2016). For the whole study period, the average percentage contribution was lower than $30 \%$ for all seasons. The highest mass contributions were usually registered during summer months, which is in agreement with the geographic location of the sampling station (Pey et al., 2013).

The annual average contribution of Saharan dust to $\mathrm{PM}_{10}$ levels was $3.3 \mathrm{\mu g} \mathrm{m}^{-3}(23.2 \%)$, a value slightly higher than that obtained for the same geographical area in a study conducted between 2001 and 2016 (Querol et al., 2019a). Nevertheless, based on the latitude of the sampling point, the average mass contribution was similar to that calculated with the equation described in Pey et al. (2013) $\left(y=1.8^{13} \cdot x^{-8}\right.$, where $x$ is the latitude and $y$ is the average African dust in $\left.\mathrm{PM}_{10}\right)$.

Similar mass contributions do not necessarily lead to similar percentage contributions, as shown in Table 2. For instance, average percentage contributions during spring and summer were quite similar $(\sim 22 \%)$, but the mass concentration of mineral dust in summer was substantially higher than that registered in spring.

On 16 out of the 376 identified dust days, the mineral dust contribution to the $\mathrm{PM}_{10}$ concentration was above $35 \mu \mathrm{g} \mathrm{m}^{-3}$, with a daily maximum value of $81 \mu \mathrm{g} \mathrm{m}^{-3}$. These values were higher than those obtained in central Mediterranean areas, like central Italy, where during the most intense episodes the calculated dust concentration reached values as high as 25 $30 \mathrm{\mu g} \mathrm{m}^{-3}$ (Nava et al., 2012). However, the values obtained in this study were lower than those registered in the eastern Mediterranean Basin (Querol et al., 2009).

\section{Atmospheric Circulation Types that Trigger SDE in the Valencian Community}

The characterization of the different atmospheric patterns that trigger SDE in the VC has been carried out by means of cluster analysis. After carrying out a preliminary study about the optimum number of clusters $\left(\mathrm{C}_{i}\right)$, five groups were chosen. Fig. 4 shows the different meteorological scenarios ( $850 \mathrm{hPa}$ geopotential height) related to each cluster. This figure also graphically depicts the circulation that triggers the arrival of Saharan dust to the VC. Overall, three baric systems, whose occurrence and mobility determined the patterns shown in Fig. 4, were identified. These systems were: a longitudinal baric gradient produced by a strong Icelandic low, low-pressure systems located west or northeast of Portugal, and a high-pressure system located over North Africa that can be longitudinally displaced from Morocco to Libya.

The percentage of days belonging to each cluster divided by season can be observed in Table 3 . The amount of days belonging to Clusters $C_{1}, C_{2}$ and $C_{5}$ was similar (16-19\%). $\mathrm{C}_{3}$ was the cluster with the highest number of days (39\%), whereas only $7.2 \%$ of the days were in $\mathrm{C}_{4}$. As can be seen, the percentage of days belonging to each cluster depended on the season. Clusters $\mathrm{C}_{2}$ and $\mathrm{C}_{4}$ were more frequent in spring, while $\mathrm{C}_{3}$ prevailed in summer. Clusters $\mathrm{C}_{1}$ and $\mathrm{C}_{5}$ were more evenly distributed throughout the year.

Fig. 4(a) shows the meteorological scenario corresponding to $\mathrm{C}_{1}$. This circulation was characterized by a high-pressure system $(\mathrm{H})$ located over northeastern Algeria, Tunisia and western Libya coupled with a trough that emanates from the Icelandic low. This meteorological scenario occurred mainly during summer, but it was also quite frequent during winter and spring (Table 3). The main loading area was located in the north of Morocco (according to the isobar pathway that passes over the monitoring point). Fig. 4(b) shows that a deep low-pressure (L) system over the west of Portugal was mainly responsible for the transport of mineral dust. This pattern predominated in spring (more than $57 \%$ of the time) and hardly ever occurred in summer. Northwestern Morocco was the main loading area in this scenario. The pattern corresponding to $\mathrm{C}_{3}$ was similar to the circulation type in Scenario 1, but a displacement of the high-pressure system to the northwest over Algeria and, to a lesser extent, Tunisia was observed (Fig. 4(c)). This scenario was the most frequent (39.2\%) and occurred mainly during summer months (69\%). In this cluster, the main source region was Algeria and the northeastern part of Morocco. The circulation type in Scenario 4 (Fig. 4(d)) was similar to $C_{2}$, although a displacement of the low-pressure system to the North Atlantic was evident. This circulation type occurred mainly in spring, and also during autumn and winter, but never occurred in summer. Cluster 4 was the least frequent circulation type and the main source region was located over the north of Morocco. The pattern belonging to $\mathrm{C}_{5}$ (Fig. 4(e)) was characterized by a highpressure system centered over Algeria and the southern Mediterranean. The potential source area was mainly located over Algeria, eastern Morocco and northwestern Libya.

It should be noted that the scenarios $\mathrm{C}_{3}$ and $\mathrm{C}_{5}$ were very similar to the meteorological patterns obtained at $850 \mathrm{hPa}$ in other studies (for instance, Scenario 4 obtained in Escudero

Table 2. Contribution $\left(\mu \mathrm{g} \mathrm{m}^{-3}\right)$ of SDE to mean seasonal $\mathrm{PM}_{10}$ concentrations.

\begin{tabular}{llllll}
\hline & 2014 & 2015 & 2016 & 2017 & Mean \\
\hline Winter & $2.1(24.7 \%)$ & $1.3(10.8 \%)$ & $4.5(40.2 \%)$ & $3.6(29.8 \%)$ & $2.9(26.4 \%)$ \\
Spring & $2.6(21.7 \%)$ & $4.0(23.4 \%)$ & $1.7(17.5 \%)$ & $3.0(23.4 \%)$ & $2.8(21.7 \%)$ \\
Summer & $1.2(6.2 \%)$ & $5.6(27.1 \%)$ & $6.6(28.6 \%)$ & $3.4(26.2 \%)$ & $4.2(22.0 \%)$ \\
Autumn & $6.5(37.1 \%)$ & $1.9(11.9 \%)$ & $3.2(21.2 \%)$ & $1.3(15.7 \%)$ & $3.2(22.5 \%)$ \\
Annual & $3.1(21.7 \%)$ & $3.2(19.4 \%)$ & $4.0(27.4 \%)$ & $2.8(24.6 \%)$ & $3.3(23.2 \%)$ \\
\hline
\end{tabular}


a)

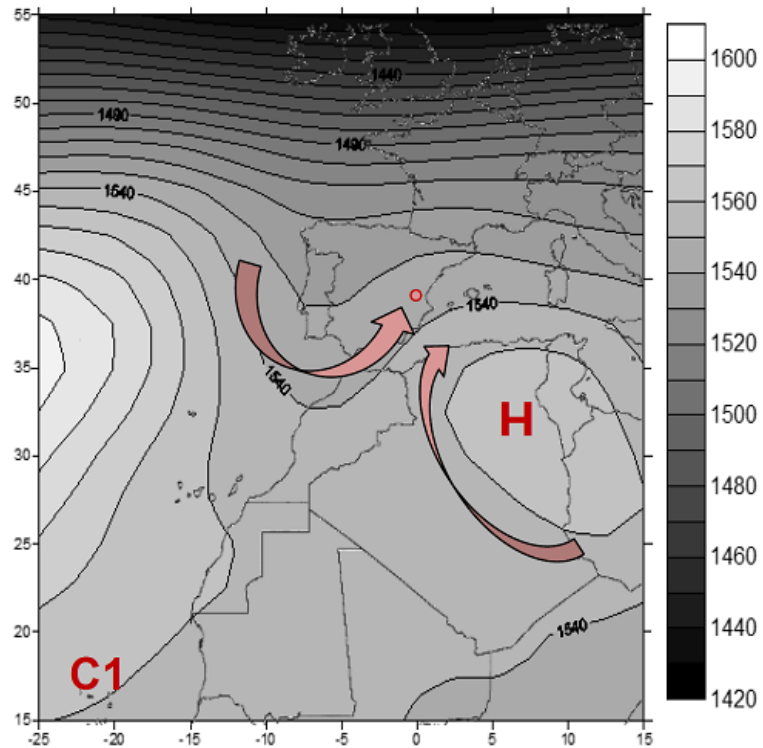

c)

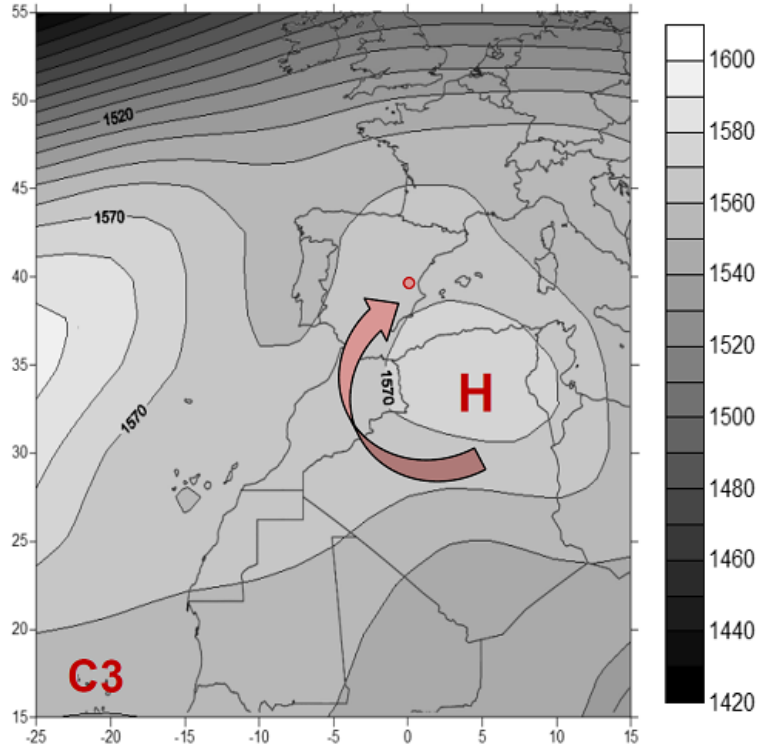

b)

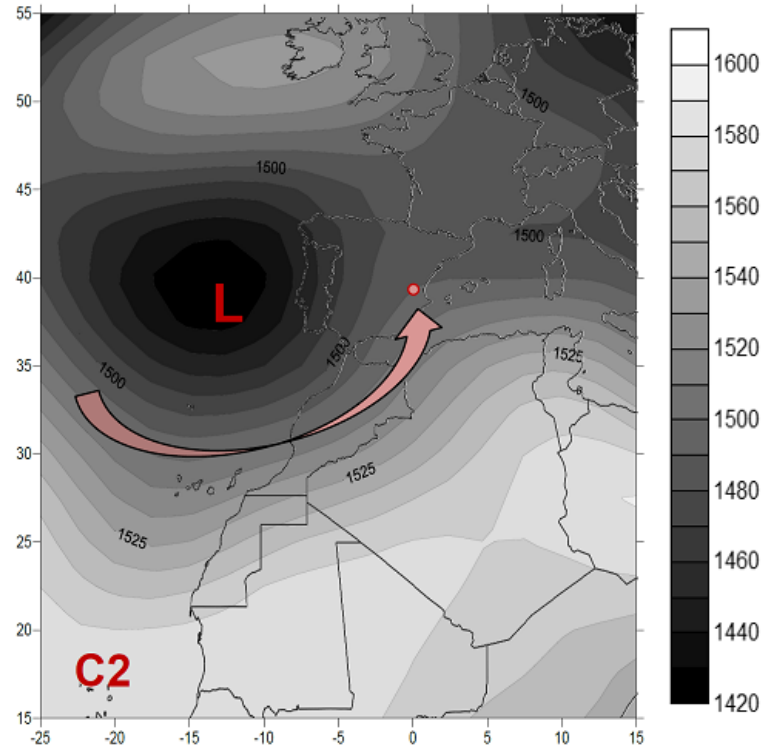

d)

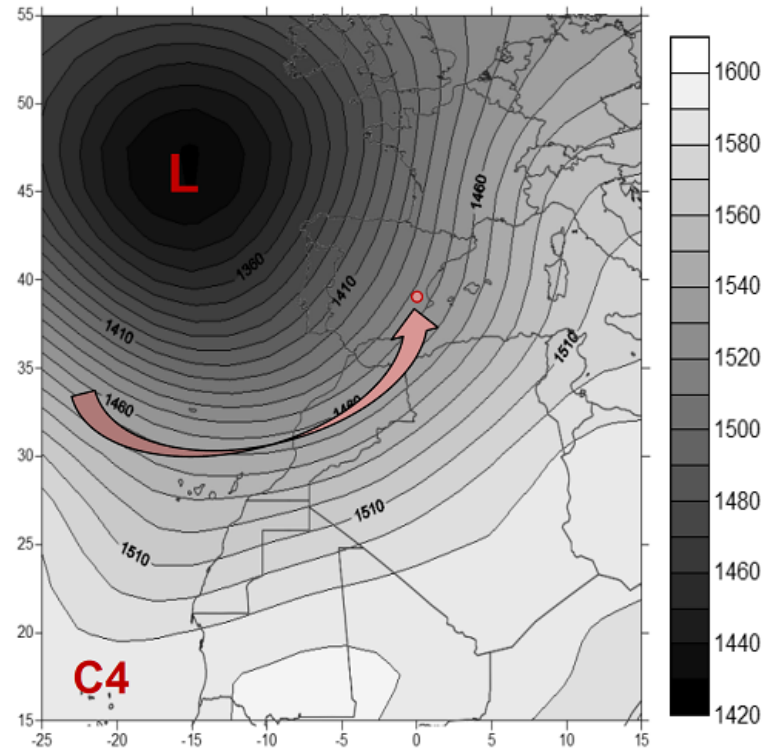

e)

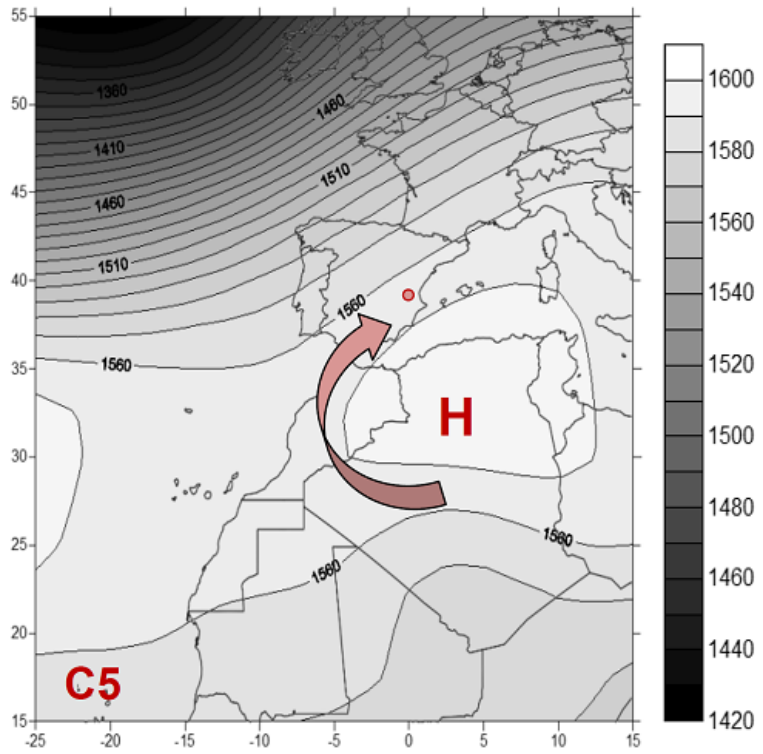

Fig. 4. Meterorological scenarios ( $850 \mathrm{hPa}$ geopotential height) related to the clusters defined. 
Table 3. Percentage of days with Saharan influence belonging to each cluster divided by season for the study period.

\begin{tabular}{llllll}
\hline & \% Winter & \% Spring & \% Summer & \% Autumn & \% Global \\
\hline $\mathrm{C}_{1}$ & 23.8 & 28.6 & 38.1 & 9.5 & 17.4 \\
$\mathrm{C}_{2}$ & 21.3 & 57.4 & 1.6 & 19.7 & 16.8 \\
$\mathrm{C}_{3}$ & 2.8 & 19.7 & 69.0 & 8.5 & 39.2 \\
$\mathrm{C}_{4}$ & 28.0 & 48.0 & 0.0 & 24.0 & 7.2 \\
$\mathrm{C}_{5}$ & 10.0 & 22.9 & 35.7 & 31.4 & 19.4 \\
\hline
\end{tabular}

et al., 2005, and Salvador et al., 2014). In these works, Scenario 4 was also more frequent in summer and was responsible for the greatest mass contributions to $\mathrm{PM}_{10}$ levels in eastern Spain. On the other hand, the source regions identified in this work are in agreement with those obtained by means of the potential source contribution function (PSCF) in Elche (southern VC; Nicolás et al., 2011). The same geographic area (Morocco and western Algeria) was identified by Mandija et al. (2017) as the main source area in Barcelona (northeastern Spain) and Granada (southern Spain).

\section{Frequency Distribution of Saharan Dust Concentrations}

Fig. 5(a) shows the gamma probability density functions of the different Saharan mass contributions obtained for each cluster. A generic characterization of these contributions can be done according to the values of the shape and scale parameters (shown in the figure). Specifically, for each cluster the Kolmogorov-Smirnov test was performed to determine the goodness of fit of the gamma distribution to the Saharan inputs. The null hypothesis $\left(\mathrm{H}_{\mathrm{o}}=\right.$ the data fits a gamma distribution) was not rejected at the $95 \%$ confidence level.

Some features can be observed from Fig. 5(a). Firstly, Clusters $C_{1}, C_{3}$ and $C_{5}$ showed the lowest values of the $\alpha$ parameter and the highest for $\beta$. It can be deduced from these values that the mass contribution of mineral dust for these clusters was most likely to be higher than for the other clusters. Besides, the shape of the probability distributions for $\mathrm{C}_{1}, \mathrm{C}_{3}$ and $\mathrm{C}_{5}$ differed from a Gaussian distribution more than the shapes for Clusters $\mathrm{C}_{2}$ and $\mathrm{C}_{4}$. Taking into account the meteorological patterns described in the previous section, it can be stated that those patterns dominated by low-pressure systems located west $\left(\mathrm{C}_{2}\right)$ and northwest $\left(\mathrm{C}_{4}\right)$ of the Iberian Peninsula were associated with the lowest mass contributions of African dust to $\mathrm{PM}_{10}$ concentrations.

Fig. 5(b) shows the probability that the mass contribution of SDE was higher than a certain value $X$. Calculations were performed using the PDF. Mass contributions were divided into four intervals from $>5 \mu \mathrm{g} \mathrm{m}^{-3}$ to $>35 \mu \mathrm{g} \mathrm{m}^{-3}$. As can be observed, $\mathrm{C}_{2}$ had the highest probability of exceeding small dust contributions $\left(5-10 \mu \mathrm{g} \mathrm{m}^{-3}\right)$, whereas $\mathrm{C}_{4}$ had the lowest probability for any given concentration. For $\mathrm{C}_{3}, \mathrm{C}_{5}$ and mainly $\mathrm{C}_{1}$, the probability of exceeding a mass contribution of $35 \mu \mathrm{g} \mathrm{m}^{-3}$ was twice and three times higher, respectively, than those for $\mathrm{C}_{2}$ and $\mathrm{C}_{4}$. From these results and those shown in Table 3, it can be stated that the greatest contribution of Saharan dust to $\mathrm{PM}_{10}$ levels in the study area was reached in summer. During spring (the season with the highest frequency of $\mathrm{C}_{2}$ and $\mathrm{C}_{4}$ ) the contribution of Saharan dust episodes was lower. This result is consistent with those presented in Table 2 .

\section{CONCLUSIONS}

The percentage of days on which the Valencian Community (VC) is influenced by Saharan dust varies significantly by year but averaged $\sim 26 \%$ annually over the study period. The highest frequency $(43 \%)$ and the longest duration of dust episodes $\left(\sim 6.7\right.$ days episode $\left.{ }^{-1}\right)$, as well as

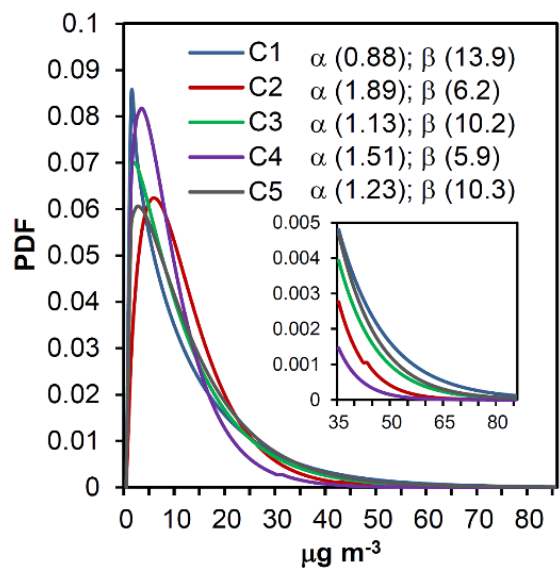

(a)

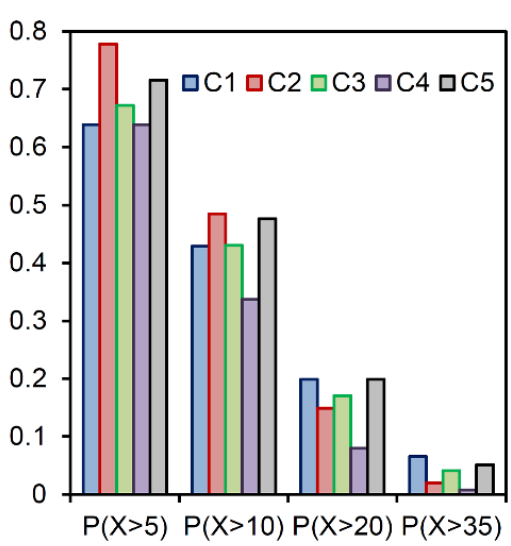

(b)

Fig. 5. (a) Gamma probability density function of dust concentrations (in $\mu \mathrm{g} \mathrm{m}^{-3}$ ) for each synoptic pattern. The scale parameter is expressed in $\mu \mathrm{g} \mathrm{m}^{-3}$ and the shape parameter is dimensionless. (b) Probability of exceeding a certain threshold value $\mathrm{X}\left(\right.$ in $\left.\mu \mathrm{g} \mathrm{m}^{-3}\right)$ using the Gamma PDF. 
the largest contributions from SDE to $\mathrm{PM}_{10}$ concentrations, occurred during summer. The average contribution of African dust for the whole period was $3.3 \mu \mathrm{g} \mathrm{m}^{-3}$ (23.2\% of the average $\mathrm{PM}_{10}$ concentration), which is consistent with our sampling point's geographic location in the Mediterranean Basin.

Specific pressure patterns on the synoptic scale induced the transport of air masses loaded with mineral dust to the study area. We identified five different meteorological scenarios based on the following baric systems: a trough emanating from an Icelandic low, the longitudinal displacement of a high-pressure system over North Africa and an Atlantic low over the western Iberian Peninsula. These scenarios exhibited certain seasonal variations. Scenarios 2 and 4, both characterized by an Atlantic low, typically arose during spring and, to a lesser extent, during the winter season. Scenario 1, produced by a North African high-pressure system combined with a longitudinal baric gradient, occurred mainly during summer, but it was also quite frequent during winter and spring. Scenarios 3 and 5, were characterized by a highpressure system over the north of Africa and appeared more often during the hot season, although the seasonality of Scenario 5 was less pronounced. The contribution of SDE to $\mathrm{PM}_{10}$ concentrations differed depending on the pressure system.

We conclude that the gamma distribution function is suitable for fitting the concentrations of Saharan dust to the $\mathrm{PM}_{10}$ levels. Our PDF analysis of each meteorological scenario revealed a lower probability of high Saharan dust concentrations for Scenarios 2 and 4. The contribution of Saharan dust to $\mathrm{PM}_{10}$ levels was largest when a North African high-pressure system was present.

\section{ACKNOWLEDGEMENTS}

This work was supported by the Spanish Ministry of Science, Innovation and Universities (COSMOS Project, ref. RTI2018-098639-B-I00). The authors would like to thank the Environmental Surveillance Network of the regional Government of Valencia for supplying the time series of $\mathrm{PM}_{10}$ used in this study, and the ACTRIS-Spain network (CGL2017-90884-REDT). The authors gratefully acknowledge the NOAA Air Resources Laboratory (ARL) for the provision of the HYSPLIT transport and dispersion model and the READY website (http://www.ready.noaa.gov) used in this publication. The authors also thank the NOAA/OAR/ESRL PSL, Boulder, Colorado, USA, for providing the meteorological dataset files used for the composition of the synoptic patterns. We acknowledge the Atmospheric Modelling \& Weather Forecasting Group at the University of Athens, the Earth Science Department from the Barcelona Supercomputing Centre, the Naval Research Laboratory and the SeaWiFS project (NASA) for the provision of SKIRON, BSC/DREAM8b, NAAPs aerosol maps and the satellite imagery, respectively.

\section{REFERENCES}

Aleksandropoulou, V. and Lazaridis, M. (2013). Identification of the influence of african dust on $\mathrm{PM}_{10}$ concentrations at the Athens air quality monitoring network during the period 2001-2010. Aerosol Air Qual. Res. 13: 1492-1503. https://doi.org/10.4209/aaqr.2012.12.0363

Alonso-Pérez, S., Cuevas, E. and Querol, X. (2011). Objective identification of synoptic meteorological patterns favouring African dust intrusions into the marine boundary layer of the subtropical eastern north Atlantic region. Meteorol. Atmos. Phys. 113: 109-124. https://doi.org/10. 1007/s00703-011-0150-z

Barnaba, F., Bolignano, B., Di Liberto, L., Morelli, M., Lucarelli, F., Nava, S., Perrino, C., Canepari, S., Basart, S., Costabile, F., Dionisi, D., Ciampichetti, S., Sozzi, R. and Gobbi, G.P. (2017). Desert dust contribution to PM $_{10}$ loads in Italy: Methods and recommendations addressing the relevant European Commission Guidelines in support to the Air Quality Directive 2008/50. Atmos. Environ. 161: 288-305. https://doi.org/10.1016/j.atmosenv.2017.04.038

Castañer, R., Nicolás, J.F., Crespo, J., Yubero, E., Galindo, N., Caballero, S. and Pastor, C. (2017). Influence of air mass origins on optical properties and PM concentrations measured at a high mountain station located in the southwestern Mediterranean. Atmos. Res. 197: 244-254. https://doi.org/10.1016/j.atmosres.2017.07.013

Conte, M., Merico, E., Cesari, D., Dinoi, A., Grasso, F.M., Donateo, A., Guascito, M.R. and Contini, D. (2020). Long-term characterisation of African dust advection in south-eastern Italy: Influence on fine and coarse particle concentrations, size distributions, and carbon content. Atmos. Res. 233: 104690. https://doi.org/10.1016/j.atmos res.2019.104690

Díaz, J., Linares, C., Carmona, R., Russo, R., Ortiz, C., Salvador, P. and Machado Trigo, R. (2017). Saharan dust intrusions in Spain: Health impacts and associated synoptic conditions. Environ. Res. 156: 455-467. https://doi.org/10.1016/j.envres.2017.03.047

Draxler, R.R. and Rolph, G.D. (2013). HYSPLIT (HYbrid Single-Particle Lagrangian Integrated Trajectory) Model Access via NOAA ARL READY Website. https://ready.arl.noaa.gov/HYSPLIT.php

Ealo, M., Alastuey, A., Ripoll, A., Pérez, N., Cruz Minguillón, M., Querol, X. and Pandolfi, M. (2016). Detection of Saharan dust and biomass burning events using near-real-time intensive aerosol optical properties in the north-western Mediterranean. Atmos. Chem. Phys. 16: 12567-12586. https://doi.org/10.5194/acp-16-125672016

Escudero, M., Castillo, S., Querol, X., Ávila, A., Alarcón, M., Viana, M.M., Alastuey, A., Cuevas, E. and Rodriguez, S. (2005). Wet and dry African dust episodes over eastern Spain. J. Geophys. Res. 110: D18S08 https://doi.org/10.1029/2004JD004731

Escudero, M., Querol, X., Pey, J., Alastuey, A., Pérez, N., Ferreira, F., Alonso, S., Rodríguez, S. and Cuevas, E. (2007). A methodology for the quantification of the net African dust load in air quality monitoring networks. Atmos. Environ. 41: 5516-5524. https://doi.org/10.1016/ j.atmosenv.2007.04.047

Fernández, A.J., Molero, F., Salvador, P., Revuelta, A., Becerril-Valle, M., Gómez-Moreno, F.J., Artíñano, B. 
and Pujadas, M. (2017). Aerosol optical, microphysical and radiative forcing properties during variable intensity African dust events in the Iberian Peninsula. Atmos. Res. 196: 129-141. https://doi.org/10.1016/j.atmosres.2017.0 6.019

Galindo, N., Yubero, E., Nicolás, J.F., Crespo, J., Varea, M. and Gil-Moltó, J. (2017). Regional and long-range transport of aerosols at Mt. Aitana, Southeastern Spain. Sci. Total Environ. 584-585: 723-730. https://doi.org/10. 1016/j.scitotenv.2017.01.108

Galindo, N., Yubero, E., Clemente, A., Nicolás, J.F., Varea, M. and Crespo, J. (2020). PM events and changes in the chemical composition of urban aerosol: A case study in the western Mediterranean. Chemosphere 244: 125520. https://doi.org/10.1016/j.chemosphere.2019.125520

García, O.E., Expósito, F.J., Díaz, J.P. and Díaz, A.M. (2011). Radiative forcing under aerosol mixed conditions. $J$. Geophys. Res. 116: D01201. https://doi.org/10.1029/200 9JD013625

Goudie, A.S. (2014). Desert dust and human health disorders. Environ. Int. 63: 101-113. https://doi.org/10.10 16/j.envint.2013.10.011

Hrdličková, Z., Michálek, J., Kolář, M. and Veselý, V. (2008). Identification of factors affecting air pollution by dust aerosol $\mathrm{PM}_{10}$ in Brno City, Czech Republic. Atmos. Environ. 42: 8661-8673. https://doi.org/10.1016/j.atmos env.2008.08.017

IPCC (2013). Climate Change 2013: The Physical Science Basis. Contribution of Working Group I to the Fifth Assessment Report of the Intergovernmental Panel on Climate Change, Stocker, T.F., Qin, D., Plattner, G.K., Tignor, M., Allen, S.K., Boschung, J., Nauels, A., Xia, Y., Bex, V. and Midgley, P.M. (Eds.), Cambridge University Press, Cambridge, United Kingdom and New York, NY, USA, pp.1535.

Jiménez, E., Linares, C., Martinez, D. and Díaz, J. (2010). Role of Saharan dust in the relationship between particulate matter and short-term daily mortality among the elderly in Madrid (Spain). Sci. Total Environ. 408: 57295739. https://doi.org/10.1016/j.scitotenv.2010.08.049

Kalnay, E., Kanamitsu, M., Kistler, R., Collins, W., Deaven, D., Gandin, L., Iredell, M., Saha, S., White, G., Woollen, J., Zhu, Y., Leetmaa, A., Reynolds, B., Chelliah, M., Ebisuzaki, W., Higgins, W., Janowiak, J., Mo, K.C., Ropelewski, C., ... Joseph, D. (1996). The NCEP/NCAR 40-year reanalysis project. Bull. Am. Meteorol. Soc. 77: 437-71. https://doi.org/10.1175/1520-0477(1996)077\%3 C0437:TNYRP\%3E2.0.CO;2

Karanasiou, A., Moreno, N., Moreno, T., Viana, M., de Leeuw, F. and Querol, X. (2012). Health effects from Saharan dust episodes in Europe: literature review and research gaps. Environ. Int. 47: 107-114. https://doi.org/ 10.1016/j.envint.2012.06.012

Mallone, S., Stafoggia, M., Faustini, A., Gobbi, G.P., Marconi, A. and Forastiere, F. (2011). Saharan dust and associations between particulate matter and daily mortality in Rome, Italy. Environ. Health Perspect. 119: 1409-1414. https://doi.org/10.1289/ehp.1003026

Mandija, F., Sicard, M., Comerón, A., Alados-Arboledas,
L., Guerrero-Rascado, J.L., Barragan, R., Bravo-Aranda, J.A., Granados-Muñoz, M.J., Lyamani, L., Muñoz Porcar, C., Rocadenbosch, F., Rodríguez, A., Valenzuela, A. and David García Vizcaíno, D. (2017). Origin and pathways of the mineral dust transport to two Spanish EARLINET sites: Effect on the observed columnar and range-resolved dust optical properties. Atmos. Res. 117: 69-83. https://doi.org/10.1016/j.atmosres.2016.12.002

Marconi, M., Sferlazzo, D.M., Becagli, S., Bommarito, C., Calzolai, G., Chiari, M., di Sarra, A., Ghedini, C., Gómez-Amo, J.L., Lucarelli, F., Meloni, D., Monteleone, F., Nava, S., Pace, G., Piacentino, S., Rugi, F., Severi, M., Traversi, R. and Udisti, R. (2014). Saharan dust aerosol over the central Mediterranean Sea: $\mathrm{PM}_{10}$ chemical composition and concentration versus optical columnar measurements. Atmos. Chem. Phys. 14: 2039-2054. https://doi.org/10.5194/acp-14-2039-2014

Nastos, P.T. (2012). Meteorological Patterns Associated with Intense Saharan Dust Outbreaks over Greece in winter. Adv. Meteorol. 2012: 828301. https://doi.org/10.1 155/2012/828301

Nava, S., Becagli, S., Calzolai, G., Chiari, M., Lucarelli, F., Prati, P., Traversi, R., Udisti, R., Valli, G. and Vecchi, R. (2012). Saharan dust impact in central Italy: An overview on three years elemental data records. Atmos. Environ. 60: 444-452. https://doi.org/10.1016/j.atmosenv.2012.0 6.064

Nicolás, J.F., Chiari, M., Crespo, J., Galindo, N., Lucarelli, F., Nava, S. and Yubero, E. (2011). Assessment of potential source regions of $\mathrm{PM}_{2.5}$ components at a southwestern Meiterranean site. Tellus B 63: 96-106. https://doi.org/10.1111/j.1600-0889.2010.00510.x

Nicolás, J.F., Crespo, J., Yubero, E., Soler, R., Carratalá, A. and Mantilla, A. (2014). Impacts on particles and ozone by transport processes recorded at urban and high-altitude monitoring stations. Sci. Total Environ. 466-467: 439436. https://doi.org/10.1016/j.scitotenv.2013.07.060

Nicolás, J.F., Castañer, R., Crespo, J., Yubero, E., Galindo, N. and Pastor, C. (2018). Seasonal variability of aerosol absorption parameters at a remote site with high mineral dust loads. Atmos. Res. 210: 100-109. https://doi.org/10. 1016/j.atmosres.2018.04.008

Ozel, G. and Cakmakyapan, S. (2015). A new approach to the prediction of $\mathrm{PM}_{10}$ concentrations in Central Anatolia Region, Turkey. Atmos. Pollut. Res. 6: 735-741. https://doi.org/10.5094/APR.2015.082

Pey, J., Querol, X., Alastuey, A., Forastiere, F. and Stafoggia, M. (2013). African dust outbreaks over the Mediterranean Basin during 2001-2011: $\mathrm{PM}_{10}$ concentrations, phenomenology and trends, and its relation with synoptic and mesoscale meteorology. Atmos. Chem. Phys. 13: 1395-1410. https://doi.org/10.5194/acp-13-1395-2013

Querol, X., Alastuey, A., Moreno, T., Viana, M.M., Castillo, S., Pey, J., Rodriguez, S., Artiñano, B., Salvador, P., Sánchez, M., García Dos Santos, S., Herce Garraleta, M.D., Fernández-Patier, R., Moreno-Grau, S., Negral, L., Minguillón, M.C., Monforte, E., Sanz, M.J., PalomoMarín, R., ... Sánchez de la Campa, A. (2008). Spatial and temporal variations in airborne particulate matter $\left(\mathrm{PM}_{10}\right.$ 
and $\mathrm{PM}_{2.5}$ ) across Spain 1999-2005. Atmos. Environ. 42: 3964-3979. https://doi.org/10.1016/j.atmosenv.2006.10. 071

Querol, X., Pey, J., Pandolfi, M., Alastuey, A., Cusack, M., Pérez, N., Moreno, T., Viana, M., Mihalopoulus, N., Kallos, G. and Kleanthous, S. (2009). African dust contributions to mean ambient $\mathrm{PM}_{10}$ mass-levels across the Mediterranean Basin. Atmos. Environ. 43: 42664277. https://doi.org/10.1016/j.atmosenv.2009.06.013

Querol, X., Pérez, N., Reche, C., Ealo, M., Ripoll, A., Tur, J., M. Pandolfi, M., Pey, J., Salvador, P., Moreno, T. and Alastuey, A. (2019a). African dust and air quality over Spain: Is it only dust that matters? Sci. Total Environ. 686: 737-752. https://doi.org/10.1016/j.scitotenv.2019.0 5.349

Querol, X., Tobías, A., Pérez, N., Karanasiou, A., Amato, F., Stafoggia, M., Pérez Garcia-Pando, C., Ginoux, P., Forastiere, F., Gumy, S., Mudu, P. and Alastuey, A. (2019b). Monitoring the impact of desert dust outbreaks for air quality for health studies. Environ. Int. 130: 104867. https://doi.org/10.1016/j.envint.2019.05.061

Rodríguez, S., Querol, X., Alastuey, A., Kallos, G. and Kakakliagou, O. (2001). Saharan dust contributions to $\mathrm{PM}_{10}$ and TSP levels in Southern and Eastern Spain. Atmos. Environ. 35: 2433-2447. https://doi.org/10.1016/ S1352-2310(00)00496-9

Salvador, P., Artíñano, B., Molero, F., Viana, M., Pey, J., Alastuey, A. and Querol, X. (2013). African dust contribution to ambient aerosol levels across central Spain: Characterization of long-range transport episodes of desert dust. Atmos. Res. 127: 117-129. https://doi.org/10. 1016/j.atmosres.2011.12.011

Salvador, P., Alonso-Pérez, S., Pey, J., Artíñano, B., de Bustos, J.J., Alastuey, A. and Querol, X. (2014). African dust outbreaks over the western Mediterranean Basin: 11year characterization of atmospheric circulation patterns and dust source areas. Atmos. Chem. Phys. 14: 67596775. https://doi.org/10.5194/acp-14-6759-2014

Titos, G., Ealo, M., Pandolfi, M., Pérez, N., Sola, Y., Sicard, M., Comerón, A., Querol, X. and Alastuey, A. (2017). Spatiotemporal evolution of a severe winter dust event in the western Mediterranean: Aerosol optical and physical properties. J. Geophys. Res. 122: 4052-4069. https://doi.org/10.1002/2016JD026252

Valenzuela, A., Olmo, F.J., Lyamani, H., Antón, M., Quirantes, A. and Alados-Arboledas, L. (2012). Classification of aerosol radiative properties during African desert dust intrusions over southeastern Spain by sector origins and cluster analysis. J. Geophys. Res. 117: D06214. https://doi.org/10.1029/2011JD016885

Received for review, February 14, 2020

Revised, April 26, 2020

Accepted, June 22, 2020 